\title{
Improvement of ovarian response and oocyte quality of aged female by administration of bone morphogenetic protein- 6 in a mouse model
}

\author{
Seung S Park', Min J Park², Bo S Joo², Jong K Joo' ${ }^{1}$, Jung B Son ${ }^{1}$ and Kyu S Lee ${ }^{1 *}$
}

\begin{abstract}
Background: Advancing female age remains a difficult problem in infertility treatment. Ovarian angiogenesis plays an important role in follicular development and the activation of ovarian angiogenesis has been emerged as a new strategy for the improvement of age-related decline of oocyte quality. BMP-6 affect gonadotropin signals in granulosa cells and it promotes normal fertility by enabling appropriate response to LH and normal oocyte quality. BMP-6 has a potential role in regulation of angiogenesis and regulates the expression of inhibitor of DNA-binding proteins (Ids). Ids involved in the control and timing of follicle selection and granulosa cells differentiation. Especially, Id-1 is well-characterized target of BMP-6 signaling. Therefore, this study investigated whether co-administration of BMP-6 during superovulation process improves ovarian response, oocyte quality and expression of Id-1 and vascular endothelial growth factor (VEGF) in the ovary of aged female using a mouse model.

Methods: Aged C57BL/6 female mice (26-31 weeks old) were superovulated by injection with $0.1 \mathrm{~mL}$ of $5 \mathrm{IU}$ equine chorionic gonadotropin (eCG) containing recombinant mouse BMP-6 at various doses $(0,0.01,0.1,1$, and $10 \mathrm{ng}$ ), followed by injection with $5 \mathrm{IU}$ human chorionic gonadotropin (hCG) $48 \mathrm{~h}$ later. Then, the mice were immediately paired with an individual male. The aged control group was superovulated without BMP-6. Young mice of 6-9 weeks old were superovulated without BMP-6 as a positive control for superovulation and in vitro culture of embryos. Eighteen hours after hCG injection, zygotes were retrieved and cultured for 4 days. Both ovaries of each mouse were provided in the examination of ovarian expression of Id-1 and VEGF by reverse transcriptase-polymerase chain reaction, western blot, and immunohistochemistry.

Results: Administration of 0.1 ng BMP-6 significantly increased the number and blastocyst formation rate of oocytes ovulated and ovarian expression of Id-1 and VEGF compared to aged control mice. These increased levels were comparable to those of young control mice.
\end{abstract}

Conclusions: This result suggests that BMP-6 during ovulation induction plays an important role in improvement of oocyte quality and ovarian response of aged female, possibly by regulating of ovarian Id-1 and VEGF expression.

Keywords: Female aging, BMP-6, Ovarian function, Oocyte quality, Id-1, VEGF

\footnotetext{
* Correspondence: kuslee@pusan.ac.kr

${ }^{1}$ Department of Obstetrics and Gynecology, Medical Research Institute, Pusan

National University School of Medicine, Busan, Korea

Full list of author information is available at the end of the article
} 


\section{Background}

Despite advancing female age becomes an important factor for increasing incidence of infertility, it remains a difficult problem in infertility treatment. A major cause for age-related decline of fertility is the deterioration of oocyte quality and ovarian response [1,2]. However, there is no clinically effective method to improve the oocyte quality in old women.

Ovarian angiogenesis plays an important role in follicular growth and the selection of dominant follicle by allowing the delivery of adequate nutrition, hormonal supply and oxygen from stromal blood vessels to induce oocytes with high quality [3-6]. Tatone et al. [7] suggested a possible mechanism that age-related nuclear and cytoplasmic damage may occur as a result of inadequate ovarian angiogenesis in primordial follicles as well as in ovarian stroma vessels. These results suggest that the activation of ovarian angiogenesis could be a new strategy for the improvement of age-related decline of oocyte quality.

Bone morphogenetic proteins (BMPs) are members of the transforming growth factor $\beta$ (TGF- $\beta$ ) superfamily which plays a critical role in the development of mammalian ovarian follicles [8,9]. Mutations in the Bmp genes or their receptors result in impaired female fertility such as decreased granulosa cell proliferation, abnormal oocyte growth, and failure of follicle development [10-13]. The BMP-6 is highly expressed in mammalian oocytes as well as other cell types $[14,15]$. In vitro extensive studies have showed that BMP-6 seems to affect gonadotropin signals in granulosa cells of several mammalian species, although it offered conflicting results [16-21]. In vivo study using BMP-6 null mice also demonstrated that BMP- 6 promotes normal fertility by enabling appropriate response to $\mathrm{LH}$ and normal oocyte quality [22].

Besides this role, BMP- 6 has a potential role in regulation of angiogenesis by affecting endothelial cells (ECs) differentiation, migration, proliferation, and tube formation [23,24]. BMP-6 regulates the expression of inhibitor of DNA-binding proteins (Ids) in the ovine ovarian follicles [25]. Id proteins are negative transcriptional regulators, which lack a basic DNA-binding domain and block subsequent transcriptional activity by forming heterodimer with helix-loop-helix (bHLH) transcription factor [26]. It has been speculated that Ids are involved in the control and timing of follicle selection and granulosa cells differentiation in avian species [27,28]. Mammalian Id superfamily consists of four isoforms (Id-1, Id-2, Id-3, and Id-4) [29]. Especially, Id-1 is a well-characterized target of BMP-6 signaling [23,24] and plays a role in angiogenesis through activation of the vascular endothelial growth factor (VEGF) [30,31].

However, to our knowledge, there have been no studies on the effects of BMP-6 on ovarian response and angiogenesis, and oocyte quality according to the female age. This study examined whether BMP-6 administration during superovulation process affects ovarian response, oocyte quality and expression of Id-1 and VEGF in the ovary of aged female using a mouse model.

\section{Methods}

This study was approved by the Institutional Review Board of Pusan National University Hospital, Korea. All experiments with mice were conducted in accordance with the Guide for the Care and Use of Laboratory Animals of the National Institutes of Health, approved by the Pusan National University Hospital Institutional Animal Care and Use Committee.

\section{Animals}

C57BL/6 inbred female mice were purchased from Korea Experimental Animal Center (Daegu, Korea). The mice were maintained on light(L)-dark(D) cycle with $14 / 10 \mathrm{~h} \mathrm{L/D}$ with food and water available ad libitum.

\section{Administration of BMP- 6 during superovulation}

Aged female mice of 26-31 weeks old were superovulated by intraperitoneal injection with $0.1 \mathrm{~mL}$ of $5 \mathrm{IU}$ equine chorionic gonadotropin (eCG) (Sigma, St. Louis, MO, USA) containing various doses ( $0,0.01,0.1,1$, and $10 \mathrm{ng})$ of recombinant mouse BMP-6 (R\&D Systems, Minneapolis, MN, USA), followed by injection of 5 IU of human chorionic gonadotropin (hCG, Sigma) approximately 48 hours later. Then the mice were immediately paired with an individual male that previously tested for fertility. The following morning the mice were inspected, and those with a confirmed vaginal plug were considered mated and fertilized. The aged control group was superovulated without BMP-6. Young mice of 6-9 weeks old were also superovulated without BMP-6 as a positive control for ovarian stimulation and in vitro culture of embryos.

\section{Zygotes collection and in vitro culture of embryos}

Eighteen hours after hCG injection, female mice with a confirmed vaginal plug were sacrificed by cervical dislocation. Cumulus-enclosed one-cell embryos (zygotes) were retrieved from the oviductal ampulae and denuded by incubation for 1 minute with $0.1 \%$ hyaluronidase (Sigma) in Dulbecco's phosphate buffered saline (dPBS; Gibco BRL, Grand Island, NY, USA). Zygotes retrieved from each were individually pooled and washed three times in P1 medium (Irvine Scientific, Santa Ana, CA, USA) with $10 \%$ serum substitute supplement (SSS; Irvine Scientific). All the zygotes except for those with cell fragmentation were cultured in $30 \mu \mathrm{l}$ drops of $\mathrm{P} 1$ medium with $10 \%$ SSS for the first 2 days, and then blastocyst medium (Irvine Scientific) with 10\% SSS for the later 2 days under paraffin-oil at $37^{\circ} \mathrm{C}$ in a $5 \% \mathrm{CO}_{2}$ humidity 
incubator. The media were changed daily as $30 \mu \mathrm{L}$-drop culture. When the retrieved one cell embryos developed to 2-cells embryo in the first day of culture, we included the data in this study. However, unless all retrieved one cell embryos developed to 2-cell embryo, we excluded the data of the mouse without developed 2-cell embryos. In this respect, we defined the retrieved one-cell embryo as real zygotes.

\section{Ovary collection and examination of ovarian Id-1 and VEGF expression}

Just after the retrieval of the zygotes, both ovaries of each mouse were collected. For the examination of ovarian expression of Id-1 and VEGF, each ovary was randomly allocated to half for reverse transcriptase-polymerase chain reaction (RT-PCR), half for western blot and a whole for immunohistochemistry (IHC).

\section{RT-PCR}

Total RNA was isolated from frozen tissue using Trizol reagent (Invitrogen, Carlsbad, CA, USA) according to the manufacturer's recommendation. RNA was eluted in RNase-free water and stored at $-80^{\circ} \mathrm{C}$ until RT-PCR analysis. The cDNA was synthesized from $5 \mu \mathrm{g}$ of total RNA with AMV Reverse Transcriptase (Promega, Madison, WI, USA) using a random hexamer (Bioneer, Daejeon, Korea) at $42^{\circ} \mathrm{C}$ for 1 hour followed by inactivate the enzyme at $95^{\circ} \mathrm{C}$ for 5 minutes. Template cDNA was subjected to PCR amplification using gene-specific sense and antisense primers. PCR conditions were denaturation at $95^{\circ} \mathrm{C}$ for 30 seconds, specific annealing temperature for 30 seconds, and extension at $72^{\circ} \mathrm{C}$ for 30 seconds in a thermal cycle. The primers of each gene are as follows: 5'-CTGC TC TACGAC ATGAACGGCTG -3' (sense) and 5'-CGACACAAGATGCGATCGTC -3' (antisense) for Id-1 (32 cycles); 5'-C T TGTTCAGAGC GGAGAAAGC- 3' (sense) and 5'-ACATCTGCAAGTACGT TCGTT-3' (antisense) for VEGF (40 cycles); and 5'-ACCACAGTCCAT GCCATCAC-3' (sense) and 5'-TCCACCACCC TGT T GCTGTA-3' (antisense) for GAPDH (25 cycles). GAPDH mRNA was quantified in each sample as an internal control to normalize the level of mRNA among samples. The PCR products were examined by $2 \%$ agarose gel electrophoresis. Data are representative of at least three independent experiments. The relative density of PCR bands were quantified and normalized relative to the control band with the National Institutes of Health (NIH) Image program (Image-J 1.35d, NIH, Bethesda, MD, USA).

\section{Western blot analysis}

Protein was extracted by homogenization of ovaries in the presence of ice-cold lysis buffer $(50 \mathrm{mM}$ Tris- $\mathrm{HCl}$ (pH 7.5), $150 \mathrm{mM} \mathrm{NaCl}, 1 \%$ Nonidet P-40, and $1 \mathrm{mM}$ EDTA) containing protease inhibitor. The protein content of the cell lysate was determined with Bradford reagent (Bio-Rad, Hercules, CA, USA) using bovine serum albumin (BSA) as the standard. Sixty micrograms of protein were separated by sodium dodecyl sulfate polyacrylamide gel electrophoresis (SDS-PAGE) and transferred to a polyvinylidene fluoride (PVDF) membrane (Millipore, Bedford, MA, USA). The membrane was incubated with anti-Id-1 polyclonal antibody (1:200; Santa Cruz Biotech, Santa Cruz, CA, USA), anti-VEGF monoclonal antibody (1:100; R\&D Systems) and anti- $\beta$-actin monoclonal antibody (1:5,000; Sigma) in tris-buffered saline (TBS) containing 1\% tween 20 (TBS-T) supplemented with skim milk overnight at $4^{\circ} \mathrm{C}$. After washing three times with TBS-T, the blotted membranes were incubated with horseradish peroxidase (HRP)-conjugated goat antibody (Santa Cruz Biotech) for 30 minutes at room temperature. After washing three times with TBS-T, the proteins bands were visualized using an enhanced chemiluminescence (ECL) detection system according to the recommended procedure (Amersham Pharmacia Biotech, Piscataway, NJ, USA). Actin expression was used as the control. Data are representative of at least three independent experiments. The relative density of protein bands were quantified and normalized relative to the control band with the National Institutes of Health (NIH) Image program (Image-J 1.35d).

\section{Immunohistochemistry}

Immunohistochemistry was performed on $4 \mu$ m-thick, formalin-fixed paraffin sections of ovary tissues using Zymed's SuperPicTure ${ }^{\mathrm{TM}}$ Polymer detection system (Zymed Laboratories-Invitrogen, San Francisco, CA, USA). Serial sections of the ovary were mounted on coated slides and placed in an oven at $60^{\circ} \mathrm{C}$ for 1 hour. The slides were then deparaffinized in xylene and dehydrated in a graded series of ethanol. The slides were boiled in $10 \mathrm{mM}$ citrate buffer ( $\mathrm{pH}$ 6.0) for 15 minutes in a microwave oven. The endogenous peroxidase was quenched with $0.3 \%$ hydrogen peroxide at room temperature for 10 minutes, and then tissues were rinsed four times for 5 minutes each in PBS. The sections were incubated overnight at $4^{\circ} \mathrm{C}$ with the primary Id-1 antibody (Santa Cruz Biotech) and VEGF antibody (Lab Vision, Fremont, CA, USA) at 1:100 dilutions. The remaining steps were performed according to the instructions supplied with the kit. After washing three times with PBS, the samples were incubated with biotinylated-conjugated secondary antibody and HRP coupled to streptavidin-conjugated antibody for 15 minutes at room temperature and washed three times with PBS. The sections were stained with 3,3-diaminobenzidine (DAB), counterstained with Mayer's hematoxylin (Sigma), and mounted with histomount solution (Invitrogen). The results were assessed by two pathologists using a light microscope. 


\section{Statistical analysis}

An SPSS program (version 12.0) was used for statistical analysis, and all data were presented as a mean \pm SD. The number of zygotes retrieved and blastocyst formation rate according to treated BMP- 6 concentration were analyzed by one-way analysis of variance with post hoc multiple comparisons by Bonferroni-Dunn analysis. Statistical analysis for comparison of expression of Id-1 and VEGF was performed by one-way ANOVA. A $P$ value of $<.05$ was considered statistically significant.

\section{Results}

To investigate whether BMP-6 effects on ovarian response and developmental competency of oocytes in aged female mice, BMP-6 was co-administered to female mice of 26-31 weeks old at different doses $(0,0.01,0.1,1$, and $10 \mathrm{ng}$ ) during superovulation. The mean number of zygotes retrieved was 14.7 in $0.1 \mathrm{ng}$ BMP-6 concentration, which was significantly increased compared to 11.6 in the aged control mice $(P<0.05)$, and this increased number was comparable to 15.1 in the young mice used as a positive control. Especially, $10 \mathrm{ng}$ BMP-6 greatly reduced the number of zygotes retrieved. On the contrary, the mean percentage of fragmented zygotes among those retrieved was $5.3 \%$ in $0.1 \mathrm{ng}$ BMP-6, which was significantly lower than those of aged control mice, $0.01 \mathrm{ng}$ and $10 \mathrm{ng}$ BMP- 6 concentrations. The development rates to blastocyst stage were also significantly increased in $0.01 \mathrm{ng}(28.1 \%)$ and $0.1 \mathrm{ng}(29.6 \%)$ BMP-6 concentrations $(P<0.05)$ when compared with $16.0 \%$ in the aged control mice, $11.6 \%$ in $1 \mathrm{ng}$ BMP-6 and 3.2\% in $10 \mathrm{ng}$ BMP-6. This increased embryo development rates in $0.01 \mathrm{ng}$ and $0.1 \mathrm{ng}$ BMP-6 were similar to that $(35.8 \%)$ of the young control mice (Table 1).

To investigate whether BMP-6 treatment during superovulation influences ovarian expressions of Id-1 and VEGF, their expressions were examined by RT-PCR and western blot in both ovaries of each mouse just after zygotes collection. Both mRNA and protein expressions of Id- 1 and VEGF were significantly stimulated by $0.1 \mathrm{ng}$ BMP-6 compared with aged controls $(P<0.05)$ and the stimulated expression levels were comparable to those of young positive control mice (Figure 1).

Immunohistochemistry was performed to evaluate the localized Id-1 and VEGF expression in only $0.1 \mathrm{ng}$ BMP-6-treated ovaries because this dose of BMP-6 resulted in a significantly effect of BMP-6 on ovarian response, oocyte quality, and the expression of Id-1 and VEGF. The expressions of Id-1 and VEGF were localized in oocytes, granulosa cells and stromal cells. The immunoreactivity of Id-1 and VEGF revealed more intense staining compared with aged control mice, but similar intense staining to that of young control (Figure 2).

\section{Discussion}

The present study shows that co-administration of BMP-6 during superovulation in aged female mice improves the number and developmental competence of oocytes ovulated in an appropriate concentration. To our knowledge, this is the first demonstration of the direct effect of BMP-6 on ovarian response, oocyte quality and ovarian expression of angiogenic-related factors of aged female using a mouse model.

The mechanisms for positive effects of BMP-6 on ovarian response and oocyte quality of aged mice are as yet unknown. However, one can consider two aspects; the first is the effect of BMP-6 itself and the second is the indirect effect of BMP- 6 via the activation of ovarian angiogenesis.

BMP- 6 was abundantly present in the granulosa cells of healthy follicle, not but in atretic follicles, of mammalian ovary [32-34] and it prevents apoptosis of cumulus cells by oocytes in a paracrine manner [17]. These results suggest that BMP-6 may be an important mediator to support healthy follicle growth in follicular development and ovarian function. This hypothesis has been supported by strong evidence of two in vivo studies by Campbell et al. [21] and Sugiura et al. [22]. Campbell et al. showed that direct ovarian infusion of BMP-6 resulted in increase in ovarian inhibin A and estradiol secretion [21]. Sugiura et al. reported that BMP-6 deficiency in female mice resulted in decreased fertility and less competent to complete

Table 1 Effect of BMP6 treatment on the number and embryo development of zygotes retrieved

\begin{tabular}{cccccccc}
\hline $\begin{array}{c}\text { Mice age } \\
\text { (weeks) }\end{array}$ & $\begin{array}{c}\text { BMP conc. } \\
\text { (ng) }\end{array}$ & $\begin{array}{c}\text { Mice } \\
\text { provided }\end{array}$ & $\begin{array}{c}\text { Zygotes } \\
\text { flushed }\end{array}$ & $\begin{array}{c}\text { Zygotes fragmented } \\
\mathbf{( \% )}\end{array}$ & $\begin{array}{c}\text { Zygotes flushed/ } \\
\text { mouse }\end{array}$ & $\begin{array}{c}\text { Zygotes } \\
\text { cultured }\end{array}$ & $\begin{array}{c}\text { Blastocyst } \\
\text { (\%) }\end{array}$ \\
\hline $\begin{array}{c}6-11 \text { (young } \\
\text { control) }\end{array}$ & 0 (control) & 7 & 118 & $12(10.2 \%)$ & $15.1 \pm 4.7^{b}$ & 106 & $38(35.8 \%)^{c}$ \\
$\begin{array}{c}26-31 \text { (aged } \\
\text { control) }\end{array}$ & 0 (control) & 7 & 93 & $12(12.9 \%)$ & $11.6 \pm 4.6$ & 81 & $13(16.0 \%)$ \\
& 0.01 & 8 & 105 & $16(15.2 \%)$ & $11.1 \pm 5.5$ & 89 & $25(28.1 \%)^{c}$ \\
& 0.1 & 11 & 171 & $9(5.3 \%)^{\mathrm{a}}$ & $14.7 \pm 2.9^{b}$ & 162 & $48(29.6 \%)^{c}$ \\
& 1 & 10 & 134 & $13(9.7 \%)$ & $12.1 \pm 4.5$ & 121 & $14(11.6 \%)$ \\
& 10 & 7 & 93 & $30(32.3 \%)$ & $9 \pm 5.6$ & 63 & $2(3.2 \%)$ \\
\hline
\end{tabular}

${ }^{\mathrm{a}} P<.01$ (vs. aged control, $0.01 \mathrm{ng}$, and $10 \mathrm{ng}$ ), ${ }^{\mathrm{b}} P<.05$ (vs. aged control, $0.01 \mathrm{ng}$, and $10 \mathrm{ng}$ ), ${ }^{\mathrm{c}} P<.05$ (vs. aged control, $1 \mathrm{ng}$ and $10 \mathrm{ng}$ ). 

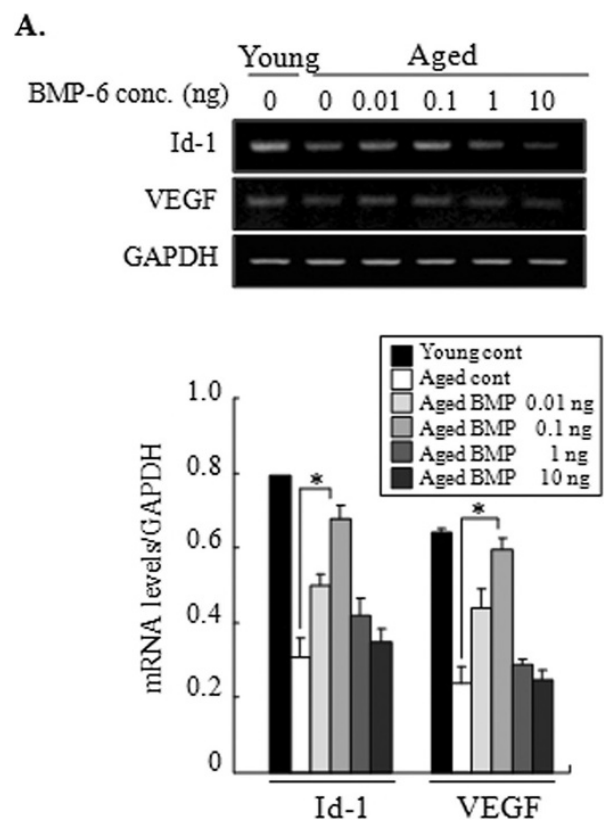

B.
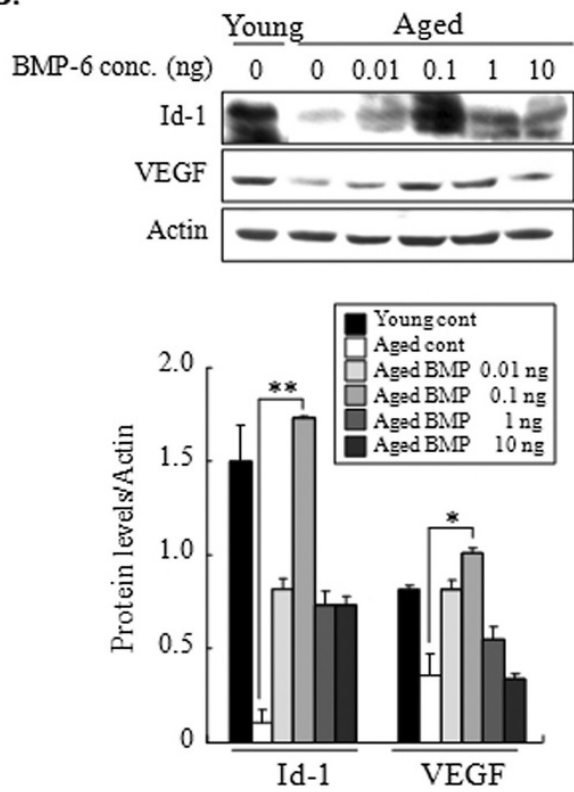

Figure 1 Effects of administration of BMP-6 on ovarian expressions of Id-1 and VEGF. Eighteen hours after hCG injection, both whole ovaries of each mouse were collected, and the expressions of ovarian Id-1 and VEGF were examined by RT-PCR and western blot. (A) Representative RT-PCR for mRNA expression of ovarian Id-1 and VEGF. Levels of mRNA for Id-1 and VEGF were normalized to the amount of GAPDH per sample. (B) Representative western blot products of protein expression for ovarian Id-1 and VEGF. Levels of protein for Id-1 and VEGF were normalized to the amount of actin per sample. Data are representative of at least three independent experiments. The relative density of each gene was quantified with $\mathrm{NIH}$-Image J program (version 1.35d) $\left({ }^{*} P<0.05\right.$ and $\left.{ }^{* *} P<0.01\right)$.

preimplantation development [22]. Due to this role of BMP-6, the administration of BMP-6 during superovulation may enhance not only ovarian response but also oocyte quality, subsequently resulting in increased embryo developmental competency.

An interesting finding in the present study was that BMP-6 treatment also stimulated the expression of Id-1 and VEGF in the ovary. This result is consistent with the report by Hogg et al. who showed that Id-1 expression was significantly increased following BMP-6 stimulation of granulosa cells in vitro [25]. VEGF is a well known representative angiogenic factor and it plays a critical role in the cyclic growth of ovarian follicles and mediates ovarian angiogenesis $[3,35]$.

Id proteins affect endothelial cells proliferation, migration, invasion, and differentiation and have an essential role in angiogenesis [24,30]. Many studies demonstrated that Id-1 stimulates angiogenesis through the activation of VEGF $[31,36]$. BMP- 6 results in an advance in the time of the LH surge [21] and LH surge have some direct effects on angiogenesis to induce a series of cellular and biochemical processes that culminate in ovulation [6]. In this regard, it can be postulated that the beneficial effect of BMP-6 on oocyte quality and ovarian response may be resulted from the activation of ovarian angiogenesis via upregulation of ovarian Id-1 and VEGF expression. Our previous studies have demonstrated that the activation of ovarian angiogenesis by administration of angiogenicstimulating factors during ovulation induction could improve ovarian response and oocyte quality with increased expression of ovarian VEGF in aged female mice [37-39]. However, we did not assess ovarian Id-1 and VEGF expression according to the time period after BMP-6 injection during the follicular development. Thus, further study is needed to elucidate when Id-1 and VEGF expression starts and continues after BMP-6 treatment.

Little data is available to confirm physiological concentrations of BMP-6 in the ovary or serum [40]. Furthermore, reports on BMP-6 levels in mice are very limited. Therefore, it was very difficult for us to determine an optimal treatment concentration of BMP-6. Brankin et al. investigated the effect of BMP-6 on steroidogenesis and cell proliferation of in vitro cultured porcine theca cells by adding various doses $(0,3,30,100 \mathrm{ng} / \mathrm{mL})$ of BMP- 6 to culture medium [41]. Estradiol production and cell proliferation were increased in $30 \mathrm{ng} / \mathrm{ml}$ BMP-6 concentration compared to other concentrations. Shi et al. treated human granulosa cells with $100 \mathrm{ng} / \mathrm{mL}$ BMP-6 for 24 hours and investigated on gene expression of FSH receptor, inhibin/activin, and anti-Mullerian hormones [15]. Campbell et al. directly infused $2 \mu \mathrm{g}$ of BMP-6 to autotransplanted ovary in sheep and examined ovarian hormone secretion [21]. Considering the BMP concentrations of these studies, we treated 100 ng BMP-6, but the 


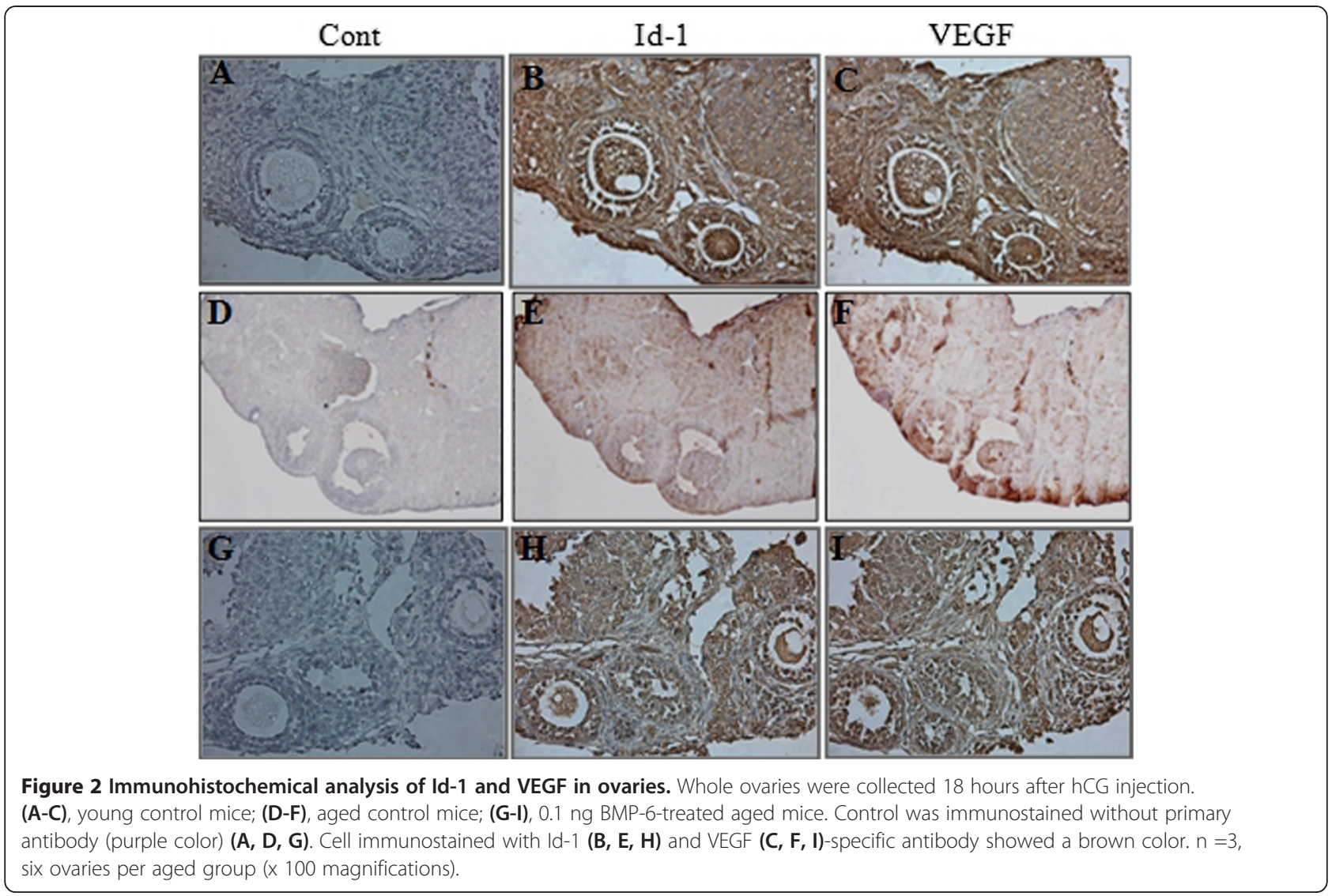

dose severely inhibited the ovarian response and the embryo development rate of retrieved zygotes. Therefore, we serially diluted this dose by ten times and treated with BMP- 6 concentrations ranging from $0.01 \mathrm{ng}$ to $10 \mathrm{ng}$. The treatment of $0.1 \mathrm{ng}$ BMP- 6 significantly increased all parameters of the number of zygotes retrieved, blastocyst formation rate, and ovarian Id-1 and VEGF expressions compared to the control and other concentrations, whereas $1 \mathrm{ng}$ and $10 \mathrm{ng}$ BMP-6 decreased the embryo development rate. Especially, $10 \mathrm{ng}$ BMP- 6 greatly reduced the number of zygotes retrieved. In this respect, it is thought that $0.1 \mathrm{ng}$ of BMP- 6 may be the optimal concentration required to improve ovarian response and oocyte quality during ovarian hyperstimulation in aged mice. The reason for inhibitory effects by high concentrations of BMP-6 (10 ng) on the number of ovulated oocytes and blastoocyst formation is not clear, but may be attributable to the increased apoptosis of granulosa cells [42].

\section{Conclusions}

The present study showed that co-administration of BMP-6 with gonadotropin during superovulation in aged mice increased the ovarian response, developmental competence of oocytes and ovarian Id-1 and VEGF expression. This study provides a notable finding that BMP-6 can stimulate oocyte quality in aged female although this study is done for a mouse model. This result suggests the possibility that this research may have potential clinical implications in the treatment of agerelated decline of fertility of women. However, our data are insufficient to apply in the human being. Therefore, first of all to apply the result of the present study, further studies are needed to investigate BMP-6 levels in human follicular fluid, serum, and ovarian tissues according to women's age, the number and quality of oocytes retrieved during in vitro fertilization and embryo transfer.

\section{Competing interests}

The authors declare that they have no competing interests.

\section{Authors' contributions}

SSP: conception and design, acquisition or analysis of data, and manuscript drafting, made the conception, participated in the design of the study and performed the statistical analysis and manuscript drafting. MJP: conception, design and execution of study, acquisition of data, participated in the conception and design of the study and performed the execution of study and acquisition of data. BSJ: execution of study, analysis of data and manuscript drafting, performed the execution of study, analysis of data and manuscript drafting. JKJ: analysis and interpretation of data, participated in analysis and interpretation of data. JBS: analysis and critical discussion, participated in analysis and critical discussion. KSL: drafting the manuscript or revising it critically for important intellectual content, and final approval of the version to be published, participated in drafting the manuscript or revising it critically for important intellectual content, and final approval of the version to be published. All authors read and approved the final manuscript. 


\section{Acknowledgements}

This work was supported by the Bio-Scientific Research Grant funded by the Pusan National University (PNU, Bio-Scientific Research Grant)

(PNU-2008 -101-208).

\section{Author details}

${ }^{1}$ Department of Obstetrics and Gynecology, Medical Research Institute, Pusan National University School of Medicine, Busan, Korea. ${ }^{2}$ Center for

Reproductive Medicine, Good Moonhwa Hospital, Busan, Korea.

Received: 25 August 2012 Accepted: 21 December 2012

Published: 29 December 2012

\section{References}

1. Navot D, Bergh PA, Williams MA, Garrisi GJ, Guzman I, Sandler B, Grunfeld L: Poor oocyte quality rather than implantation failure as a cause of agerelated decline in female fertility. Lancet 1991, 337:1375-1377.

2. Tarin JJ, Perez-Albala S, Cano A: Cellular and morphological traits of oocytes retrieved from aging mice after exogenous ovarian stimulation. Biol Reprod 2001, 65:141-150.

3. Geva E, Jaffe RB: Role of vascular endothelial growth factor in ovarian physiology and pathology. Fertil Steril 2000, 74:429-438.

4. Fraser HM: Regulation of the ovarian follicular vasculature. Reprod Biol Endocrinol 2006, 4:18.

5. Robinson RS, Woad KJ, Hammond AJ, Laird M, Hunter MG, Mann GE: Angiogenesis and vascular function in the ovary. Reproduction 2009, 138:869-881.

6. Araújo VR, Duarte $A B$, Bruno JB, Pinho Lopes CA, de Fiqueiredo JR: Importance of vascular endothelial growth factor (VEGF) in ovarian physiology of mammals. Zygote 2011, 13:1-10.

7. Tatone C, Amicarelli F, Carbone MC, Monteleone P, Caserta D, Marci R, Artini PG, Piomboni P, Focarelli R: Cellular and molecular aspects of ovarian follicle ageing. Hum Reprod Update 2008, 14:131-142.

8. Knight PG, Glister C: TGF-beta superfamily members and ovarian follicle development. Reproduction 2006, 132:191-206.

9. Shimasaki S, Moore RK, Otsuka F, Erickson GF: The bone morphogenetic protein system in mammalian reproduction. Endocr Rev 2004, 25:72-101.

10. Dong J, Albertini DF, Nishimori K, Kumar TR, Lu N, Matzuk MM: Growth differentiation factor-9 is required during early ovarian folliculogenesis. Nature 1996, 383:531-535.

11. Edson MA, Nalam RL, Clementi C, Franco HL, Demayo FJ, Lyons KM, Pangas SA, Matzuk MM: Granulosa cell-expressed BMPR1A and BMPR1B have unique functions in regulating fertility but act redundantly to suppress ovarian tumor development. Mol Endocrinol 2010, 24:1251-1266.

12. Yi SE, Lapolt PS, Yoon BS, Chen JY, Lu JK, Lyons KM: The type I BMP receptor BmprlB is essential for female reproductive function. Proc Nat Acad Sci USA 2001, 98:7994-7949.

13. Gode F, Gulekli B, Dogan E, Korhan P, Dogan S, Bige O, Cimrin D, Atabey N: Influence of follicular fluid GDF9 and BMP15 on embryo quality. Fertil Steril 2011, 95:2274-2278.

14. Otsuka F, Moore RK, Shimasaki S: Biological function and cellular mechanism of bone morphogenetic protein- 6 in the ovary. $J$ Biol Chem 2001, 276:32889-32895.

15. Shi J, Yoshino O, Osuga Y, Koga K, Hirota Y, Hirata T, Yano T, Nishii O, Taketani Y: Bone morphogenetic protein- 6 stimulates gene expression of follicle-stimulating hormone receptor, inhibin/activin beta subunits, and anti-müllerian hormone in human granulosa cells. Fertil Steril 2009, 92:1794-1798.

16. Glister C, Richards SL, Knight PG: Bone morphogenetic proteins (BMP) $-4,-6$, and -7 potently suppress basal and luteinizing hormone-induced androgen production by bovine theca interna cells in primary culture: could ovarian hyperandrogenic dysfunction be caused by a defect in thecal BMP signaling? Endocrinology 2005, 146:1883-1892.

17. Hussein TS, Froiland DA, Amato F, Thompson JG, Gilchrist RB: Oocytes prevent cumulus cell apoptosis by maintaining a morphogenic paracrine gradient of bone morphogenetic proteins. J Cell Sci 2005, 118:5257-5268.

18. Juengel JL, Reader KL, Bibby AH, Lun S, Ross I, Haydon L, McNatty KP: The role of bone morphogenetic proteins 2, 4, 6 and 7 during ovarian follicular development in sheep: contrast to rat. Reproduction 2006, 131:501-513.

19. Miyoshi T, Otsuka F, Inagaki K, Otani H, Takeda M, Suzuki J, Goto J, Ogura T, Makino $\mathrm{H}$ : Differential regulation of steroidogenesis by bone morphogenetic proteins in granulosa cells: involvement of extracellularly regulated kinase signaling and oocyte actions in follicle-stimulating hormone-induced estrogen production. Endocrinology 2007, 148:337-345.

20. Campbell BK, Souza CJ, Skinner AJ, Webb R, Baird DT: Enhanced response of granulosa and theca cells from sheep carriers of the FecB mutation in vitro to gonadotropins and bone morphogenic protein-2, -4 and -6. Endocrinology 2006, 147:1608-1620.

21. Campbell BK, Kendall NR, Baird DT: Effect of direct ovarian infusion of bone morphogenetic protein 6 (BMP-6) on ovarian function in sheep. Biol Reprod 2009, 81:1016-1023.

22. Sugiura K, Su YQ, Eppig JJ: Does bone morphogenetic protein 6 (BMP-6) affect female fertility in the mouse? Biol Reprod 2010, 83:997-1004.

23. Ren R, Charles PC, Zhang C, Wu Y, Wang H, Patterson C: Gene expression profiles identify a role for cyclooxygenase 2-dependent prostanoid generation in BMP-6-induced angiogenic responses. Blood 2007, 109:2847-2853.

24. Valdimarsdottir G, Goumans MJ, Rosendahl A, Brugman M, Itoh S, Lebrin F, Sideras $P$, ten Dijke P: Stimulation of Id1 expression by bone morphogenetic protein is sufficient and necessary for bone morphogenetic protein-induced activation of endothelial cells. Circulation 2002, 106:2263-2270.

25. Hogg K, Etherington SL, Young JM, McNeilly AS, Duncan WC: Inhibitor of differentiation (Id) genes are expressed in the steroidogenic cells of the ovine ovary and are differentially regulated by members of the transforming growth factor-beta family. Endocrinology 2010, 151:1247-1256

26. O'Toole PJ, Inoue T, Emerson L, Morrison IE, Mackie AR, Cherry RJ, Norton JD: Id proteins negatively regulate basic helix-loop-helix transcription factor function by disrupting subnuclear compartmentalization. J Biol Chem 2003, 278:45770-45706.

27. Johnson AL, Haugen MJ, Woods DC: Role for inhibitor of differentiation/ deoxyribonucleic acid-binding (Id) proteins in granulosa cell differentiation. Endocrinology 2008, 149:3187-3195.

28. Johnson AL, Woods DC: Dynamics of avian ovarian follicle development cellular mechanisms of granulosa cell differentiation. Gen Comp Endocrinol 2009, 163:12-17.

29. Barone MV, Pepperkok R, Peverali FA, Philipson L: Id proteins control growth induction in mammalian cells. Proc Natl Acad Sci USA 1994, 91:4985-4988.

30. Benezra R, Rafii S, Lyden D: The Id proteins and angiogenesis. Oncogene 2001, 20:8334-8341.

31. Ling MT, Lau TC, Zhou C, Chua CW, Kwok WK, Wang Q, Wang X, Wong YC: Overexpression of Id- 1 in prostate cancer cells promotes angiogenesis through the activation of vascular endothelial growth factor (VEGF). Carcinogenesis 2005, 26:1668-1676.

32. Hino J, Takao M, Takeshita N, Konno Y, Nishizawa T, Matsuo H, Kangawa K: cDNA cloning and genomic structure of human bone morphogenetic protein-3B (BMP-3b). Biochem Biophys Res Commun 1996, 223:304-310.

33. Erickson GF, Shimasaki S: The spatiotemporal expression pattern of the bone morphogenetic protein family in rat ovary cell types during the estrous cycle. Reprod Biol Endocrinol 2003, 1:9.

34. Erickson GF, Fuqua L, Shimasaki S: Analysis of spatial and temporal expression patterns of bone morphogenetic protein family members in the rat uterus over the estrous cycle. J Endocrinol 2004, 182:203-217.

35. Stouffer RL, Martínez-Chequer JC, Molskness TA, Xu F, Hazzard TM: Regulation and action of angiogenic factors in the primate ovary. Arch Med Res 2001, 32:567-575.

36. Kim HJ, Chung H, Yoo YG, Kim H, Lee JY, Lee MO, Kong G: Inhibitor of DNA binding 1 activates vascular endothelial growth factor through enhancing the stability and activity of hypoxia-inducible factor-1alpha. Mol Cancer Res 2007, 5:321-329.

37. Lee DH, Joo BS, Suh DS, Park JH, Choi YM, Lee KS: Sodium nitroprusside treatment during the superovulation process improves ovarian response and ovarian expression of vascular endothelial growth factor in aged female mice. Fertil Steril 2008, 89:1514-1521.

38. Joo JK, Joo BS, Kim SC, Choi JR, Park SH, Lee KS: Role of leptin in improvement of oocyte quality by regulation of ovarian angiogenesis. Anim Reprod Sci 2010, 119:329-334.

39. Choi KH, Joo BS, Sun ST, Park MJ, Son JB, Joo JK, Lee KS: Administration of visfatin during superovulation improves developmental competency of oocytes and fertility potential in aged female mice. Fertil Steril 2012, 97:1234-1241. e3. 
40. Glister C, Kemp CF, Knight PG: Bone morphogenetic protein (BMP) ligands and receptors in bovine ovarian follicle cells: actions of BMP-4, -6 and -7 on granulosa cells and differential modulation of smad-1 phosphorylation by follistatin. Reproduction 2004, 127:239-254.

41. Brankin V, Quinn RL, Webb R, Hunter MG: BMP-2 and -6 modulate porcine theca cell function alone and co-cultured with granulosa cells. Domest Anim Endocrinol 2005, 29:593-604.

42. Kayamori T, Kosaka N, Miyamoto A, Shimizu T: The differential pathways of bone morphogenetic protein (BMP)-4 and -7 in the suppression of the bovine granulosa cell apoptosis. Mol Cell Biochem 2009, 323:161-168.

doi:10.1186/1477-7827-10-117

Cite this article as: Park et al: Improvement of ovarian response and oocyte quality of aged female by administration of bone morphogenetic protein- 6 in a mouse model. Reproductive Biology and Endocrinology 2012 10:117.

\section{Submit your next manuscript to BioMed Central and take full advantage of:}

- Convenient online submission

- Thorough peer review

- No space constraints or color figure charges

- Immediate publication on acceptance

- Inclusion in PubMed, CAS, Scopus and Google Scholar

- Research which is freely available for redistribution 